Journal of Agricultural Sciences
(Tarim Bilimleri Dergisi)

\title{
The Estimation of Live Weight from Body Measurements in Different Meat-Type Lambs
}

\author{
Vasfiye KADER ESEN ${ }^{a^{*}}$ D, Cengiz ELMACI ${ }^{b}$ (D)

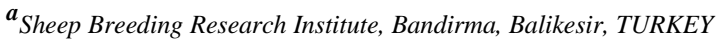

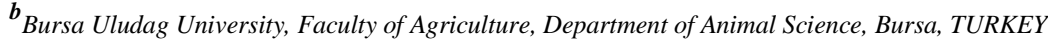 \\ ARTICLE INFO \\ Research Article \\ Corresponding Author: Vasfiye KADER ESEN, E-mail: vasfiye.esen@gmail.com \\ Received: 13 April 2020 / Revised: 25 May 2020 / Accepted: 12 June 2020 / Online: 04 December 2021
}

\section{ABSTRACT}

The present study aimed to analyze the live weight (LW) and some body measurements to estimate the LW of lambs in five different meat-type sheep breeds reared in the same flock under intensive conditions. A total of 202 head of lambs, including both genders of Kivircik (K), Bandirma (B), Karacabey Merino (KM), Hampshire Down x Merino crossbreed (HM), and Ramlic (R), were conducted in this study. Birth weights ranged between $3.94-5.07 \mathrm{~kg}$ in those breeds and were affected significantly by breed and birth types $(\mathrm{P}<0.001)$. The effect of sex was clearly seen with the weaning period; males lambs were $2.61 \mathrm{~kg}$ heavier than female lambs $(\mathrm{P}<0.001)$. The importance of breed differences on chest circumference (CC) increased as the lambs grew older. On the other hand, sex had a significant effect on all body measurements at the pre- and post-weaning period $(\mathrm{P}<0.01$ and $\mathrm{P}<0.001)$; however, did not on body length $(\mathrm{BL})$ at the pre-weaning period $(\mathrm{P}>0.05)$. In contrast, the importance of birth type on $\mathrm{BL}$ and $\mathrm{CC}$ decreased as the lambs grew older $(\mathrm{P}>0.05)$. The results of regressing LW and body measurements show that LW was very highly $(\mathrm{P}<0.001)$ correlated with body measurements $(r=0.682-0.892)$. The highest correlations were observed between LW and CC ( $r=0.802-0.892)$ in $\mathrm{B}, \mathrm{KM}$, and $\mathrm{R}$ lambs. These results suggest that using body measurements as a correction factor has a great benefit in those breeds, such as withers height and $\mathrm{CC}$ are used to estimate $\mathrm{LW}$ in $\mathrm{KM}$ and $\mathrm{R}$ lambs, effectively.

Keywords: Estimation, Body measurements, Live weight, Sheep breeds

(c) Ankara University, Faculty of Agriculture

\section{Introduction}

Sheep breeding plays a crucial role in enhancing the rural economy, and it is known by one of the most adaptive small ruminants to adverse environmental conditions in Turkey. Despite its great impact on the rural economy, the extensive lamb production system is still practiced in most of the country with traditional methods of management and natural grazing (Kaymakçı \& Sönmez 1996; Akçapınar 2000). There are more than 37 million sheep with various native breeds in different geographical regions of Turkey (TurkStat 2019). Approximately $80-90 \%$ of Turkey's sheep populations are fat-tailed breeds, such as Akkaraman in the Central Anatolia, Morkaraman in the Eastern Anatolia, Awassi in the Southeastern Anatolia. There have also been thin-tailed breeds like Chios and Kivircik crossbreeds in the Aegean, Pirlak in the Mediterranean, and Karayaka in the Black Sea region. These native breeds are generally resistant to disease, tolerate extreme temperatures, have a strong flocking instinct, and can able to adapt poor nursing and feeding conditions. Nowadays, sheep meat plays an important role in demanding red meat production. On the other hand, the latest statistic shows that it is far from meeting the increasing demand of the growing human population because only $9.1 \%$ of total red meat production is covered by sheep meat in Turkey (TurkStat 2019). This situation is in contradiction with Turkey's well-known property as a country of small ruminants. Crossbreeding studies of native breeds with Merino, fast-growing and early developing breeds, and Kivircik, known as having good quality carcass and flavor, have increased with consideration of consumer preferences in the last few decades (Akçapınar et al. 2001; Yılmaz et al. 2002; Ekiz \& Altınel 2006). Although it is necessary to define the factors associated with age, live weight (LW), and body measurements not only to select better animals to achieve more genetic improvement and reproductive efficiency but also high carcass yield in domesticated sheep breeding (Aksoy et al. 2019). Various studies showed that body measurements could be used to study the interaction between heredity and environment (Wolf et al. 1981; Vatankhah \& Talebi 2008), and in assessing growth rate, feed utilization, and carcass characteristics in farm animals (Kirton et al. 1995; Sar1 et al. 2014; Da Silva 2019) and LW can be predicted from body measurements (Ali et al. 2014; Sari et al. 2014; Şahin et al. 2018). Also, estimating the LW using body measurements is more practical than weighting in rural areas because of requiring less labor. The aim of the current study was to evaluate the effects of breed type, as well as birth type, sex, and age of dam, on early growth performance; and to get a simple linear regression equation of LW, especially for small-scale farm owners, in Kivircik (K), Bandirma (B, German Black Head Mutton x Kivircik crossbreed), Karacabey Merino (KM), Hampshire Down x Merino crossbreed (HM), and Ramlic (R) lambs under intensive conditions. 


\section{Material and Methods}

\subsection{Animals and measurements}

The data in this study originated from the flocks of Sheep Breeding Research Institute, Balikesir, Turkey. A total of 202 head of lambs, K (n=51; 36 Female (F), 15 Male (M)), B (n=49; 34 F, 15 M), KM (n=47; 33F, 14 M), HM (n=27; 16 F, 11 M), and R $(\mathrm{n}=28 ; 14 \mathrm{~F}, 14 \mathrm{M})$, were used in this study. The reproduction system was based on a once-a-year mating; the general breeding season was started in June, leading to lambing ewes between November and January. During pre-weaning time, lambs have suckled their mothers, and from 15 days of age, they had access to commercial starter feed and alfalfa hay ad libitum, and they weaned at an average age of $90 \pm 6$ days. At the beginning of May 2018, a single flock was created from later-born lambs to investigate the variation in genes affecting growth, meat quality, and yield in these meat-type sheep breeds. Lambs were housed in cross-ventilated pens and had free access to water and mineral licking stones. An average $600 \mathrm{~g} / \mathrm{lamb}$ of concentrate feed, 100 $\mathrm{g} / \mathrm{lamb}$ of alfalfa hay, and $300 \mathrm{~g} / \mathrm{lamb}$ of vetches-wheat mixtures hay per day were given up to post-weaning period (135 days of age).

Body measurements considered in this study were lamb LW, body length (BL), withers height (WH), back height (BH), and chest circumference $(\mathrm{CC})$ measurements.

LW of lambs was recorded at birth, weaning (90 days of age), and 135 days of age for calculation of the average daily gain (ADG) and standardized for pre- and post-weaning LW. Individual LW of lambs was determined prior to before morning feeding to avoid error due to stomach fill. Body linear measurements were taken on animals in a standing position with a raised head by the same technician in order to avoid intra-individual variations, according to Yilmaz et al. (2013). Circumference was measured with a flexible calibrated tape, whereas calipers were used for length and width.

All animal care and handling procedures of the present study were reviewed and approved by the Ethical Committee of the Sheep Breeding Research Institute (Approval number:13360037). All efforts were made to minimize any discomfort during body measurements.

\subsection{Statistical analysis}

The effect of independent factors (breed type, sex of lamb, birth type, and age of dam) on considered traits were analyzed using the GLM procedure of Minitab (2014) statistical package programs, and least-squares means were compared using the Tukey's multiple comparison tests. The model used for the least-squares (LS) analysis was as follows:

$Y_{i j k l m}=\mu+B_{i}+S_{j}+T_{k}+A_{l}+E_{i j k l m}$

Where: $\mathrm{Y}_{\mathrm{ijklm}}=$ the observation of the $\mathrm{m}^{\text {th }}$ animal within the $\mathrm{l}^{\text {th }}$ age group of the $\mathrm{k}^{\text {th }}$ type of birth and $\mathrm{j}^{\text {th }}$ sex category of the $\mathrm{i}^{\text {th }}$ breed; $\mu$ : overall mean; $B_{i}$ : effect of the $i^{\text {th }}$ breed $(i: \mathrm{K}, \mathrm{B}, \mathrm{KM}, \mathrm{HM}, \mathrm{R}) ; S_{j}$ : effect of the $j^{\text {th }}$ sex $\left(j:\right.$ male, female); $T_{k}$ : effect of the $k^{\text {th }}$ type of birth ( $k$ : single, twin); $A_{l}$ : effect of the dam $l^{\text {th }}$ age $(l: 2,3,4,5,6,7+) ; E_{i j k l m}:$ residual error.

Stepwise multiple regressions were fitted to get a prediction equation of LW from body measurements considering raw correlations between all studied body measurements. The REG procedure of Minitab (2014) was used to determine the relative importance of body measurements.

\section{Results and Discussion}

In the present study, LW and some body measurements of K, B, KM, HM, and R lambs were determined, which are essential to evaluate some production characteristics of lambs from meat-type breeds. Results of LS means and standard errors (SE) of LW and average daily gain (ADG) at different periods are given in Table 1 . Single lambs were $0.68 \mathrm{~kg}$ heavier $(\mathrm{P}<0.001)$ at birth than those born as twins. With the exception of birth weight, all LW was significantly greater in males than females $(\mathrm{P}<0.001)$. Birth weights ranged between 3.94-5.07 kg in K, B, KM, HM, and R $(\mathrm{P}<0.001)$. Also, the average birth weight of KM and HM lambs were significantly different from K, B, and R lambs. Age of dam or sex did not, however, breed and birth type affect birth weight. Such differences have been well documented by Bingöl \& Bingöl (2015) and Öztürk et al. (2012).

At weaning age (90 days) and up to the post-weaning (135 days) period, a significant difference in LW was observed between those breeds (Table 1). HM and KM lambs were $20.59 \%$ and $24.26 \%$ heavier than B lambs at birth (5.07 and 4.92 versus 4.08 $\mathrm{kg}, \mathrm{P}<0.001)$ but at weaning period bodyweight of $\mathrm{B}$ lambs became the highest one $(34.44 \mathrm{~kg}, \mathrm{P}<0.001)$. This difference between those three breed types tended to decrease with age, and the advantage of B lambs in LW did not persist in the post-weaning period. Conversely, there were no significant differences observed between $\mathrm{K}$ and $\mathrm{R}$ lambs in all periods. The results obtained from the present study on birth weight, especially for K, KM, HM breeds were higher than several estimates in the literature, for example, Koyuncu et al. (1999), Cemal et al. (2005), Koyuncu \& Uzun (2009). 
Table 1- LS means $( \pm$ SE) of $L W(\mathrm{~kg})$ and ADG (g/day) different periods

\begin{tabular}{|c|c|c|c|c|c|c|c|}
\hline \multirow[b]{2}{*}{ Factors } & \multicolumn{3}{|c|}{$L W$} & \multirow[b]{2}{*}{135 days } & \multirow[b]{2}{*}{$\begin{array}{r}\text { Pre-weaning } \\
(0-90 \text { days })\end{array}$} & \multirow[b]{2}{*}{$\begin{array}{l}\text { Post-weaning } \\
(90-135 \text { days })\end{array}$} & \multirow[b]{2}{*}{$\begin{array}{c}\text { Overall } \\
(0-135 \text { days })\end{array}$} \\
\hline & $\begin{array}{l}\text { No. of } \\
\text { lambs }\end{array}$ & $\begin{array}{c}\text { Birth } \\
\text { (0 days) }\end{array}$ & $\begin{array}{l}\text { Weaning } \\
\text { (90 days) }\end{array}$ & & & & \\
\hline Breed type & & $* * *$ & $* * *$ & $* * *$ & **** & **** & $* * *$ \\
\hline $\mathrm{K}$ & 51 & $3.94 \pm 0.11^{\mathbf{b}}$ & $28.92 \pm 0.53^{c}$ & $35.73 \pm 0.68^{\mathbf{b}}$ & $277.63 \pm 5.36^{\mathrm{cd}}$ & $133.21 \pm 7.97^{\mathbf{b}}$ & $235.52 \pm 4.76^{b}$ \\
\hline $\mathrm{B}$ & 49 & $4.08 \pm 0.11^{\mathbf{b}}$ & $34.44 \pm 0.53^{\mathrm{a}}$ & $40.84 \pm 0.68^{a}$ & $337.39 \pm 5.38^{\mathrm{a}}$ & $144.64 \pm 7.99^{\mathbf{b}}$ & $272.32 \pm 4.78^{a}$ \\
\hline $\mathrm{KM}$ & 47 & $4.92 \pm 0.10^{\mathrm{a}}$ & $31.60 \pm 0.48^{\mathbf{b}}$ & $40.77 \pm 0.62^{a}$ & $296.39 \pm 4.92^{\mathbf{b c}}$ & $200.94 \pm 7.30^{\mathrm{a}}$ & $265.53 \pm 4.37^{\mathrm{a}}$ \\
\hline $\mathrm{HM}$ & 27 & $5.07 \pm 0.14^{\mathrm{a}}$ & $32.77 \pm 0.67^{\mathbf{a b}}$ & $41.98 \pm 0.86^{\mathrm{a}}$ & $307.71 \pm 6.82^{\mathbf{b}}$ & $203.00 \pm 10.10^{\mathrm{a}}$ & $273.37 \pm 6.05^{\mathrm{a}}$ \\
\hline $\mathrm{R}$ & 28 & $4.17 \pm 0.14^{\mathbf{b}}$ & $27.90 \pm 0.67^{\mathbf{c}}$ & $35.03 \pm 0.86^{\mathbf{b}}$ & $263.62 \pm 6.81^{d}$ & $165.40 \pm 10.10^{\mathbf{b}}$ & $228.54 \pm 6.05^{\mathbf{b}}$ \\
\hline Sex of lamb & & $\mathrm{NS}$ & $* * *$ & $* * *$ & $* * *$ & $* * *$ & $* * *$ \\
\hline Male & 69 & $4.49 \pm 0.09$ & $32.43 \pm 0.43^{\mathrm{a}}$ & $41.77 \pm 0.55^{a}$ & $310.39 \pm 4.38^{\mathbf{a}}$ & $204.55 \pm 6.51^{\mathrm{a}}$ & $276.17 \pm 3.89^{a}$ \\
\hline Female & 133 & $4.38 \pm 0.07$ & $29.83 \pm 0.36^{\mathbf{b}}$ & $35.97 \pm 0.46^{\mathbf{b}}$ & $282.71 \pm 3.66^{\mathbf{b}}$ & $134.30 \pm 5.44^{\mathbf{b}}$ & $233.95 \pm 3.25^{\mathbf{b}}$ \\
\hline Birth type & & $* * *$ & $* * *$ & $* * *$ & $* * *$ & NS & $* *$ \\
\hline Single & 97 & $4.78 \pm 0.08^{\mathrm{a}}$ & $32.43 \pm 0.38^{\mathrm{a}}$ & $40.08 \pm 0.49^{a}$ & $307.28 \pm 3.84^{\mathrm{a}}$ & $169.72 \pm 5.70$ & $261.50 \pm 3.41^{\mathrm{a}}$ \\
\hline Twin & 105 & $4.10 \pm 0.08^{\mathbf{b}}$ & $29.82 \pm 0.41^{\mathbf{b}}$ & $37.66 \pm 0.53^{\mathbf{b}}$ & $285.82 \pm 4.15^{\mathbf{b}}$ & $169.13 \pm 6.17$ & $248.62 \pm 3.69^{b}$ \\
\hline Age of dam & & $\mathrm{NS}$ & $\mathrm{NS}$ & $\mathrm{NS}$ & $\mathrm{NS}$ & NS & $\mathrm{NS}$ \\
\hline 2 & 7 & $3.87 \pm 0.27$ & $29.64 \pm 1.34$ & $37.90 \pm 1.71$ & $286.30 \pm 13.60$ & $172.70 \pm 20.20$ & $252.10 \pm 12.00$ \\
\hline 3 & 26 & $4.40 \pm 0.13$ & $32.08 \pm 0.66$ & $39.92 \pm 0.85$ & $307.57 \pm 6.69$ & $171.09 \pm 9.94$ & $263.16 \pm 5.94$ \\
\hline 4 & 30 & $4.59 \pm 0.13$ & $30.86 \pm 0.62$ & $38.84 \pm 0.80$ & $291.88 \pm 6.34$ & $174.22 \pm 9.41$ & $253.70 \pm 5.63$ \\
\hline 5 & 40 & $4.47 \pm 0.11$ & $31.01 \pm 0.54$ & $39.01 \pm 0.69$ & $294.90 \pm 5.47$ & $174.74 \pm 8.13$ & $255.83 \pm 4.86$ \\
\hline 6 & 48 & $4.65 \pm 0.10$ & $31.76 \pm 0.49$ & $38.97 \pm 0.62$ & $301.17 \pm 4.93$ & $162.65 \pm 7.32$ & $254.18 \pm 4.38$ \\
\hline $7+$ & 51 & $4.64 \pm 0.09$ & $31.41 \pm 0.46$ & $38.58 \pm 0.59$ & $297.49 \pm 4.67$ & $161.14 \pm 6.94$ & $251.42 \pm 4.15$ \\
\hline
\end{tabular}

$L W$ : Live weight; $A D G$ : Average daily gain; $K$ : Kivircik; $B$ : Bandirma; KM: Karacabey Merino; HM; Hampshire Down $\mathrm{x}$ Merino crossbreed; $R$ : Ramlic. Different letters $(\mathrm{a}, \mathrm{b}, \mathrm{c})$ in the same column are statistically different $(\mathrm{P}<0.05)$. NS: Not Significant; **: $\mathrm{P}<0.01 ; * * *: \mathrm{P}<0.001$

ADG is one of the most important indicators of the profitability of lamb production in both pre- and post-weaning periods. ADG of lambs was significantly affected by sex and breed type $(\mathrm{P}<0.001)$. With the exception of the post-weaning period, birth type affected ADG while the age of the dam did not. From birth to 90 days of age, B lambs had higher ADG than the other breeds (337.39 g, P<0.001). On the other hand, HM and KM lambs had higher ADG from 90 to 135 days of age than the other breeds (Table 1). Also, single-born lambs had higher ADG at the pre-weaning period $(21.46 \mathrm{~g} /$ day; $\mathrm{P}<0.001)$ and higher overall $\mathrm{ADG}$ $(12.88 \mathrm{~g} /$ day; $\mathrm{P}<0.01)$ compared with twins. However, the effect of birth type was not significant at post-weaning $(\mathrm{P}>0.05)$. The present findings are in agreement with the results reported by other authors (Cemal et al. 2005; Koyuncu \& Uzun 2009; Norouzian 2015).

To estimate genetic inheritance, the morphological differences among breeds could be used as an indicator for each sheep breed (Marković et al. 2019). Also, estimating the environmental effects on these traits is important for manipulating management practices to get more income. In the current study, the results of body measurements at weaning (90 days of age) and 135 days of age are presented in Table 2. CC has been suggested to be the most satisfactory single variable in estimating LW by Ibiwoye et al. (1993). In the current study, B and KM lambs had higher CC at the weaning period (P<0.01). Moreover, the differences between $\mathrm{CC}$ of lambs became more significant, and HM lambs had higher CC at the post-weaning period $(\mathrm{P}<0.001)$. The results of CC obtained from the conducted study are higher than reports of Isik \& Aksoy (2015) for CC traits in Bafra sheep breed at 6 months age.

Another trait that could be used to estimate body weight is WH. Topal and Macit (2004) reported that the combination of WH and CC could be used to estimate body weight in Morkaraman sheep. WH was varied between 56.06-58.16 cm at weaning and 61.56-64.12 cm at 135 days of age within those breeds. WH of male lambs were 1.95 and $2.65 \mathrm{~cm}$ higher than female lambs at weaning and 135 days of age-old, respectively $(\mathrm{P}<0.001)$. Similar results were obtained by Silva Souza et al. (2019) for Piata, Xaraes, and Paiaguas sheep breeds at 270 days of age in Brazil. Also, considering the weaning and post-weaning periods obtained results for BL and BH were consistent with the literature (Akçapınar et al. 2001; Ambarcioglu et al. 2017; Sahin et al. 2018).

The results from this study indicate that the importance of breed differences on CC increased as the lambs grew older. On the other hand, sex had a significant effect on all body measurements at the pre- and post-weaning period (significance varied between $\mathrm{P}<0.01$ and $\mathrm{P}<0.001)$; however, did not on $\mathrm{BL}$ pre-weaning period $(\mathrm{P}>0.05)$. In contrast, the importance of birth type on WH and CC decreased as the lambs grew older. This may be explained by differences in the characteristics of those breeds (Y1lmaz et al. 2013). 
Table 2- LS means $( \pm$ SE) of body measurements $(\mathrm{cm})$ at weaning (90 days of age) and post-weaning time (135 days of age)

\begin{tabular}{|c|c|c|c|c|c|c|c|c|c|c|}
\hline \multirow[b]{2}{*}{ Factors } & \multicolumn{5}{|c|}{ Weaning (90 days) } & \multicolumn{5}{|c|}{ Post-weaning (135 days) } \\
\hline & $N$ & $B L$ & $W H$ & BH & $C C$ & $N$ & $B L$ & WH & $B H$ & $C C$ \\
\hline \multirow[t]{4}{*}{ Breed type } & & $* * *$ & $* * *$ & $* * *$ & $* *$ & & $* * *$ & $* * *$ & $* * *$ & $* * *$ \\
\hline & & $60.32 \pm$ & $57.61 \pm$ & $58.13 \pm$ & $74.22 \pm$ & & $63.29 \pm$ & $63.40 \pm$ & $63.50 \pm$ & $78.02 \pm$ \\
\hline & 51 & $0.52^{\mathbf{b}}$ & $0.38^{\mathrm{a}-\mathrm{c}}$ & $0.40^{\mathrm{ab}}$ & $0.67^{\mathrm{ab}}$ & 51 & $0.51^{\mathrm{b}}$ & $0.36 \mathrm{a}$ & $0.36^{\mathbf{a b}}$ & $0.67^{\mathbf{b}}$ \\
\hline & & $62.18 \pm$ & $58.16 \pm$ & $58.00 \pm$ & $76.08 \pm$ & & $66.65 \pm$ & $63.32 \pm$ & $63.19 \pm$ & $81.55 \pm$ \\
\hline \multirow[t]{2}{*}{ B } & 49 & $0.52^{\mathrm{a}}$ & $0.39^{\mathbf{a b}}$ & $0.40^{\mathbf{a b}}$ & $0.67^{\mathrm{a}}$ & 49 & $0.51^{\mathrm{a}}$ & $0.36^{\mathrm{a}}$ & $0.36^{\mathbf{b}}$ & $0.67^{\mathrm{a}}$ \\
\hline & & $60.41 \pm$ & $58.88 \pm$ & $59.43 \pm$ & $75.01 \pm$ & & $65.19 \pm$ & $64.12 \pm$ & $64.68 \pm$ & $81.23 \pm$ \\
\hline \multirow[t]{2}{*}{ KM } & 47 & $0.47^{\mathbf{a b}}$ & $0.35^{\mathrm{a}}$ & $0.36^{\mathrm{a}}$ & $0.61^{\mathrm{a}}$ & 47 & $0.47^{\mathrm{a}}$ & $0.33^{\mathrm{a}}$ & $0.33^{\mathrm{a}}$ & $0.61^{\mathrm{a}}$ \\
\hline & & $59.71 \pm$ & $56.66 \pm$ & $57.11 \pm$ & $74.27 \pm$ & & $66.01 \pm$ & $63.27 \pm$ & $63.20 \pm$ & $82.16 \pm$ \\
\hline \multirow[t]{2}{*}{ HM } & 27 & $0.66^{\mathbf{b}}$ & $0.49^{\mathbf{b c}}$ & $0.50^{\mathbf{b c}}$ & $0.85^{\mathrm{ab}}$ & 27 & $0.65^{\mathrm{a}}$ & $0.46^{\mathbf{a b}}$ & $0.46^{\mathbf{a b}}$ & $0.85^{\mathrm{a}}$ \\
\hline & & $56.77 \pm$ & $56.06 \pm$ & $56.01 \pm$ & $71.75 \pm$ & & $61.79 \pm$ & $61.56 \pm$ & $60.64 \pm$ & $77.45 \pm$ \\
\hline $\mathrm{R}$ & 28 & $0.66^{\mathrm{c}}$ & $0.49^{c}$ & $0.50^{\mathrm{c}}$ & $0.85^{\mathbf{b}}$ & 28 & $0.65^{\mathbf{b}}$ & $0.46^{\mathrm{b}}$ & $0.46^{\mathrm{c}}$ & $0.85^{\mathbf{b}}$ \\
\hline \multirow[t]{2}{*}{ Sex of lamb } & & NS & **** & $* * *$ & $* *$ & & $* * *$ & $* * *$ & $* * *$ & $* * *$ \\
\hline & & $60.29 \pm$ & $58.45 \pm$ & $58.75 \pm$ & $75.24 \pm$ & & $65.98 \pm$ & $64.46 \pm$ & $64.39 \pm$ & $81.50 \pm$ \\
\hline \multirow[t]{2}{*}{ Male } & 69 & 0.42 & $0.31^{\mathrm{a}}$ & $0,32^{\mathbf{a}}$ & $0.55^{\mathrm{a}}$ & 69 & $0.42^{\mathrm{a}}$ & $0.30^{\mathrm{a}}$ & $0.30^{\mathrm{a}}$ & $0.55^{\mathrm{a}}$ \\
\hline & & $59.47 \pm$ & $56.50 \pm$ & $56.72 \pm$ & $73.29 \pm$ & & $63.19 \pm$ & $61.81 \pm$ & $61.69 \pm$ & $78.67 \pm$ \\
\hline Female & 133 & 0.35 & $0.26^{b}$ & $0.27^{\mathbf{b}}$ & $0.46^{\mathrm{b}}$ & 133 & $0.35^{\mathbf{b}}$ & $0.25^{\mathbf{b}}$ & $0.25^{\mathbf{b}}$ & $0.46^{b}$ \\
\hline \multirow[t]{2}{*}{ Birth type } & & NS & $* * *$ & $* * *$ & $* *$ & & NS & $* *$ & $* * *$ & $*$ \\
\hline & & $60.30 \pm$ & $58.25 \pm$ & $58.65 \pm$ & $75.21 \pm$ & & $64.90 \pm$ & $63.71 \pm$ & $63.64 \pm$ & $80.82 \pm$ \\
\hline \multirow[t]{2}{*}{ Single } & 97 & 0.37 & $0.28^{\mathrm{a}}$ & $0.28^{\mathrm{a}}$ & $0.48^{\mathrm{a}}$ & 97 & 0.37 & $0.26^{\mathrm{a}}$ & $0.26^{\mathrm{a}}$ & $0.48^{\mathrm{a}}$ \\
\hline & & $59.46 \pm$ & $56.70 \pm$ & $56.82 \pm$ & $73.32 \pm$ & & $64.27 \pm$ & $62.56 \pm$ & $62.44 \pm$ & $79.35 \pm$ \\
\hline Twin & 105 & 0.40 & $0.30^{\mathbf{b}}$ & $0.31^{\mathbf{b}}$ & $0.52^{\mathrm{b}}$ & 105 & 0.40 & $0.28^{\mathbf{b}}$ & $0.28^{\mathbf{b}}$ & $0.52^{b}$ \\
\hline
\end{tabular}

$K$ : Kivircik; $B$ : Bandirma; KM: Karacabey Merino; $H M$ :Hampshire Down x Merino crossbreed; $R$ : Ramlic. $B L$ : Body length; WH: Withers height; $B H$ : Back height; $C C$ : Chest circumference; Different letters (a, b, c, d) in the same column are statistically different $(\mathrm{P}<0.05)$. N: Number of lambs; NS: Not Significant; $: \mathrm{P}<0.05 ; * *: \mathrm{P}<0.01 ; * * *: \mathrm{P}<0.001$

Except for some fluctuations, B and KM lambs were highest for all physical measurements during the pre-weaning period. This might be attributed to the superiority of mothering ability and the higher birth weight of these breeds. These results are consistent with a previous study conducted for Hamari and Kabashi breeds (Ali et al. 2014).

The results of regressing LW and body measurements are presented in Table 3. In general terms, LW was very highly $(\mathrm{P}<0.001)$ correlated with body measurements $(r=0.682-0.892)$. In $\mathrm{B}, \mathrm{KM}$, and $\mathrm{R}$ lambs, the highest correlations were observed between LW and CC (0.802-0.892), whereas BL (0.864) and WH (0.784) was the most correlated trait with LW in HM and K lambs, respectively. On the other hand, the least correlation between LW and other traits was observed in K, KM, and R lambs for BL (0.764-0.837); HM lambs for WH (0.854), and B lambs for BH values (0.682). The obtained results of phenotypic correlation coefficients between LW and body measurements were lower than the results obtained from four different Iranian sheep (Mehrebani, Zandi, Shaal, and Macoei) breeds (Shirzeyli et al. 2013). The difference between those breeds is natural due to having different morphology. 
Table 3- Phenotypic correlations between body measurements in different meat-type lambs

\begin{tabular}{|c|c|c|c|c|c|c|c|c|c|c|c|c|c|c|c|c|c|c|c|c|}
\hline Trait & & & $L W$ & & & & & $B L$ & & & & & $W H$ & & & & & $B H$ & & \\
\hline Breed & $\star$ & $\infty$ & $\sum$ & $\mathbb{I}$ & $\approx$ & $\star$ & $\infty$ & $\sum$ & $\mathbb{X}$ & $\approx$ & 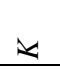 & $\infty$ & 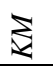 & $\mathbb{I}$ & $\approx$ & $\star$ & $\infty$ & $\Sigma$ & $\mathbb{Z}$ & $\approx$ \\
\hline BL & 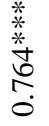 & 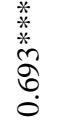 & 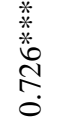 & 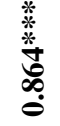 & 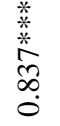 & & & & & & & & & & & & & & & \\
\hline WH & $\begin{array}{l}\stackrel{*}{*} \\
\stackrel{+}{*} \\
\stackrel{\infty}{0}\end{array}$ & 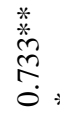 & 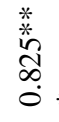 & 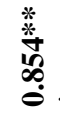 & 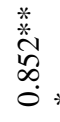 & $\begin{array}{l}\frac{*}{*} \\
\stackrel{*}{0} \\
\stackrel{0}{0}\end{array}$ & $\begin{array}{l}\text { 券 } \\
\text { 总 } \\
0 \\
0 \\
0\end{array}$ & 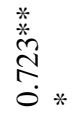 & 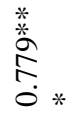 & $\begin{array}{l}\text { * } \\
\stackrel{*}{0} \\
\stackrel{\infty}{\infty} \\
\stackrel{0}{0} *\end{array}$ & & & & & & & & & & \\
\hline BH & 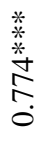 & 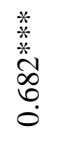 & 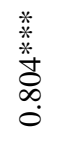 & 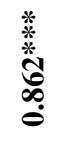 & 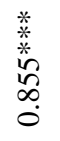 & 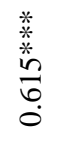 & 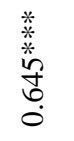 & $\begin{array}{l}\frac{*}{*} \\
\stackrel{*}{*} \\
\stackrel{2}{\circ}\end{array}$ & 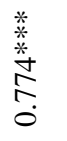 & 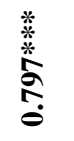 & $\frac{\stackrel{*}{*}}{\stackrel{*}{*}}$ & 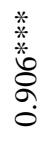 & 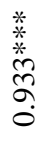 & 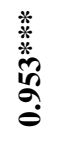 & 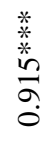 & & & & & \\
\hline $\mathrm{CC}$ & 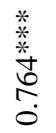 & 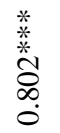 & 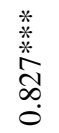 & 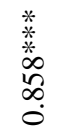 & 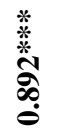 & $\begin{array}{l}\frac{*}{*} \\
\stackrel{*}{*} \\
\stackrel{0}{0} \\
\stackrel{0}{0} \\
\stackrel{0}{0}\end{array}$ & 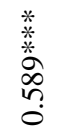 & 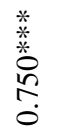 & 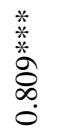 & 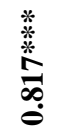 & $\begin{array}{l}* \\
* \\
* \\
0 \\
0 \\
\vdots \\
0 \\
0\end{array}$ & 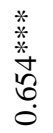 & $\begin{array}{l}\text { *.* } \\
\stackrel{*}{*} \\
\stackrel{\sim}{0} \\
\stackrel{0}{0}\end{array}$ & 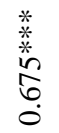 & $\begin{array}{l}\text { * } \\
\stackrel{*}{*} \\
\stackrel{*}{*} \\
\stackrel{8}{8}\end{array}$ & 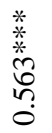 & $\begin{array}{l}\frac{*}{*} \\
\text { 音 } \\
\text { in } \\
0\end{array}$ & 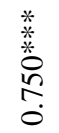 & $\begin{array}{l}\text { *. } \\
\stackrel{*}{*} \\
0 \\
0 \\
0\end{array}$ & $\begin{array}{l}\stackrel{*}{*} \\
\stackrel{*}{*} \\
\stackrel{0}{\Theta}\end{array}$ \\
\hline
\end{tabular}

K: Kivircik; B: Bandirma; KM: Karacabey Merino; HM: Hampshire Down x Merino crossbreed; R: Ramlic.; LW: Live weight; $B L:$ Body length; WH: Withers height; $B H$ : Back height; $C C$ : Chest circumference; ***: $\mathrm{P}<0.001$

As understood from Table 3, it was seen that body measurements such as CC and WH had a high relationship with LW of lambs in those sheep breeds. Also, there was a moderate to a strong relationship between the other studied body measurements (0.589-0.953). Inconsistent with this study, Afolayan et al. (2006) noted that various body measurements related to animal size and weight display moderate to a high correlation between one another. The obtained correlation between LW and BL (0.6930864), LW, and WH (0.733-0.854), LW, and CC (0.764-0.892) were higher than obtained results from Mahmut et al. (2014) except BL (0.693) for B lambs and CC (0.764) for K lambs.

Multiple regression analysis was also performed to get simple linear regression and partial regression equations for those breeds. According to obtained results, as shown in Tablo 4, there was no significant effect of sex on regression analysis for $\mathrm{R}$ lambs. The lowest and the highest determination coefficient $\left(\mathrm{R}^{2)}\right.$ value was found in $\mathrm{B}$ and $\mathrm{H}$ lambs as 0.75 and 0.92 , respectively. Eck et al. (2019) noted that although the high correlation between WH and BH, using WH as a correction factor has a great benefit instead of BH because the lambs stood better on their forelegs than on their hind legs. The results obtained from our study are in accordance with this study, but they differ due to the significant effect of BH on the regression equation. The differences between morphological characters of breeds, weaning time, location, season, or breeding systems may be the reason among these two studies.

Table 4- Simple linear regression equations for estimating $L W$ in different meat-type lambs

\begin{tabular}{|c|c|c|c|c|}
\hline Breed & $\operatorname{Sex}$ & Equation & $R^{2}$ & $M S E$ \\
\hline \multirow{2}{*}{$\mathrm{K}$} & $\begin{array}{c}\mathrm{M} \\
\mathrm{F}\end{array}$ & $L W=-53.82+0.383(B L)+0.286(W H)+0.293(B H)+0.378(C C)$ & 0.84 & 2.12 \\
\hline & - & $L W=-63.93+0.482(B L)+0.283(W H)+0.329(B H)+0.385(C C)$ & 0.81 & 2.29 \\
\hline \multirow[t]{2}{*}{ B } & $\begin{array}{c}\mathrm{M} \\
\mathrm{F}\end{array}$ & $L W=-48.68+0.326(B L)+0.317(W H)+0.593(C C)$ & 0.75 & 2.46 \\
\hline & - & $L W=-51.95+0.326(B L)+0.360(W H)+0,592(C C)$ & 0.74 & 2.48 \\
\hline \multirow[t]{2}{*}{ KM } & $\begin{array}{c}\mathrm{M} \\
\mathrm{F}\end{array}$ & $L W=-53.51+0.795(W H)+0.527(C C)$ & 0.79 & 2.93 \\
\hline & - & $L W=-55.55+0.782(W H)+0.556(C C)$ & 0.79 & 2.94 \\
\hline \multirow[t]{2}{*}{$\mathrm{HM}$} & $\begin{array}{c}\mathrm{M} \\
\mathrm{F}\end{array}$ & $L W=-47.53+0.296(B L)+0.385(W H)+0.140(B H)+0.460(C C)$ & 0.92 & 1.91 \\
\hline & - & $L W=-55.01+0.315(B L)+0.663(B H)+0.416(C C)$ & 0.89 & 2.16 \\
\hline $\mathrm{R}$ & $\begin{array}{c}\mathrm{M} \\
\mathrm{F} \\
-\end{array}$ & $L W=-50.10+0.594(W H)+0.630(C C)$ & 0.86 & 2.28 \\
\hline
\end{tabular}

$K$ : Kivircik; $B$ : Bandirma; KM: Karacabey Merino; $H M$ : Hampshire Down x Merino crossbreed; $R:$ Ramlic.; $M$ : Male; $F$ : Female; $L W$ : Live weight; $B L:$ Body length; $W H$ : Withers height; $B H$ : Back height; $C C$ : Chest circumference; $R^{2}$, Determination coefficient; $M S E$ : Mean square error 


\section{Conclusions}

LW and body measurements are important indicators to predict the growth of both indigenous and crossbred sheep breeds. They can be used to select animals with better production characteristics that result in increased production, productivity, and profitability of the farm. The results from the present study indicated that the relationships between LW and body measurements are affected by such factors of breed and birth type with sex differences in those meat-type sheep breeds. Obtained results from this study also show that B, KM, and HM lambs were notably heavier and grew faster than K and R lambs, and had better growth characteristics in the same rearing system. Also, some useful information was collected that could be used in selection programs and obtained some regression equations to estimate LW from body measurements. Moreover, the high correlations between LW and such body measurements, e.g., WH and CC, would imply these two traits could be used to determine LW effectively in KM and $\mathrm{R}$ lambs rather than $\mathrm{BL}$ and $\mathrm{BH}$.

\section{Acknowledgments}

The present study was supported by the Republic of Turkey, Ministry of Agriculture and Forestry, General Directorate of Agricultural Research (Project No: TAGEM/HAYSUD/B/18/A4/P2/308).

\section{References}

Afolayan R A, Adeyinka I A \& Lakpini C A M (2006). The estimation of live weight from body measurements in Yankasa sheep. Czech Journal of Animal Science 51(8): 343-348

Akçapınar H (2000). Koyun Yetiştiriciliği. Genişletilmiş 2. Baskı. İsmat Matbaacılık, Ankara (In Turkish)

Akçapınar H, Ünal N \& Özbeyaz C (2001). The possibilities of developing dam and sire lines using Akkaraman, Sakız (Chios) and Kıvırcık sheep breeds for lamb production II. Some body measurements in lambs and some production traits in yearling females. Lalahan Hayvancılık Araştırma Dergisi 41(1): 25-33 (In Turkish)

Aksoy A, Ertürk Y E, Eyduran E \& Tariq M M (2019). Utility of MARS algorithm for describing non-genetic factors affecting pasture revenue of Morkaraman breed and Romanov $\times$ Morkaraman F1 crossbred sheep under semi intensive conditions. Pakistan Journal of Zoology 51: 235-240 http://doi.org/10.17582/journal.pjz/2019.51.1.235.240

Ali M, Abdella H O, Elimam M E, Sulieman A H, El-Hag F M, Eshag N A \& Jadalla J B (2014). Pre-weaning body measurements and performance of desert sheep (Tribal subtypes Hamari and Kabashi) lambs of Kordofan Region, Sudan. Malaysian Journal of Animal Science 17(1): $35-45$

Ambarcioglu P, Kaya U, Ozen D \& Gurcan I S (2017). An examination of the relationships between live weight and body measurements in Karacabey Merino sheep through the path analysis approach. Kafkas Üniversitesi Veteriner Fakültesi Dergisi 23(6): 853-857 http://doi.org/10.9775/kvfd.2017.17659

Bingöl E \& Bingöl M (2015). The growth of lambs and body measurement traits of Hamdani ewes. Yüzüncü Yıl Üniversitesi Tarım Bilimleri Dergisi 25(2): 200-206 http://doi.org/10.29133/yyutbd.236274 (In Turkish)

Cemal I, Karaca O, Altin T \& Kaymakc1 M (2005). Live weights of Kivircik ewes and lambs in some periods under extensive management conditions. Turkish Journal of Veterinary and Animal Sciences 29(6): 1329-1335

Da Silva N C, Raphael C G, Chaves A S, Luciana C G, Mendes Athayde A L \& Letícia F C (2019). Morphometric measurements of sheep fed with increasing levels of sunflower meal. Acta Scientiarum Animal Sciences 41: e42891 http://doi.org/10.4025/actascianimsci.v41i1.42891

Eck K, Kunz E, Mendel C, Luhken G \& Medugorac I (2019). Morphometric measurements in lambs as a basis for future mapping studies. Small Ruminant Research 181: 57-64 http://doi.org/0.1016/j.smallrumres.2019.04.007

Ekiz B \& Altinel A (2006). The growth and survival characteristics of lambs produced by commercial crossbreeding Kivircik ewes with F2 rams with the German black-headed mutton genotype. Turkish Journal of Veterinary and Animal Sciences 30(6): 507-512

Ibiwoye T I I, Oyatogun M O \& Jolayemi J (1993). Yankasa sheep and West African dwarf goat production in the Kainji lake basin of Nigeria. Tropical Agriculture (Trinidad and Tobago) 70 (2): 165-168

Isik S A \& Aksoy A R (2015). The growth traits of Bafra sheep (Chios x Karayaka B1) at Kazim Karabekir Agriculture Centre. Van Veterinary Journal 26(2): 93-99 (In Turkish)

Kaymakçı M \& Sönmez R (1996). İleri Koyun Yetiştiriciliği. Ege Üniversitesi Basımevi, İzmir (In Turkish)

Kirton A H, Carter A H, Clarke J N, Sinclair D P, Mercer G J K, \& Duganzich D M (1995). A comparison between 15 ram breeds for export lamb production I. Liveweights, body components, carcass measurements, and composition. New Zealand Journal of Agricultural Research 38(3): 347-360

Koyuncu M \& Uzun S K (2009). Growth performance of Karacabey Merino and Kivircik lambs under semi-intensive management in Turkey. Small Ruminant Research 83(1-3): 64-66 http://doi.org/10.1016/j.smallrumres.2009.03.001

Koyuncu M, Ipek A, Tuncel E \& Akgündüz V (1999). Some yield characteristics of genotype groups obtained by crossbreeding Kivircik with imported mutton sheep breeds (Hampshire Down, Lincoln and Blackhead German). Turkish Journal of Veterinary and Animal Sciences 23 (EK2): 423-428 (In Turkish)

Mahmud M A, Shaba P, Abdulsalam W, Yisa H Y, Gana, Ndagi S \& Ndagimba R (2014). Live body weight estimation using cannon bone length and other body linear measurements in Nigerian breeds of sheep. Journal of Advanced Veterinary and Animal Research 1(4): 169176 http://doi.org/10.5455/javar.2014.a29

Marković B, Dovč P, Marković M, Radonjić D, Adakalić M \& Simčič M (2019). Differentiation of some Pramenka sheep breeds based on morphometric characteristics. Archives Animal Breeding 62: 393-402 http://doi.org/10.5194/aab-62-393-2019

Minitab (2014). Minitab I: Statistical Software for Windows, Release 17. Minitab Incorporation, USA

Norouzian M A (2015). Effects of lambing season, birth type and sex on early performance of lambs. New Zealand Journal of Agricultural Research 58(1): 84-88 https://doi.org/10.1080/00288233.2014.944270

Ozturk Y, Kucuk M \& Karsli M (2012). A study on growth, slaughter and carcass traits of Morkaraman and Kivircik x Morkaraman (F1) lambs in semi-intensive condition. Kafkas Universitesi Veteriner Fakültesi Dergisi 18(1): 1-6 https://doi.org/0.9775/kvfd.2011.4351 
Sarı M, Önk K, Aksoy A R, Tilki M \& Işı S (2014). Determination of growth and some body measurements of Hemşin lambs. Lalahan Hayvancılık Araştırma Enstitüsü Dergisi 54(1): 15-20 (In Turkish)

Sari M, Onk K, Aydin E, Tilki M, \& Tufan T (2014). Effects of different fattening systems on fattening performance and body measurements of Hemsin male lambs. Kafkas Universitesi Veteriner Fakultesi Dergisi 20(2): 209-215 https://doi.org/10.9775/kvfd.2013.9823

Shirzeyli F H, Lavvaf A \& Asadi A (2013). Estimation of body weight from body measurements in four breeds of Iranian sheep. Songklanakarin Journal of Science \& Technology 35(5): 507-511

Silva Souza J D, do Santos Difante G, Neto J V E, Lana A M Q, da Silva Roberto F F \& Ribeiro P H C (2019). Biometric measurements of Santa Inês meat sheep reared on Brachiaria brizantha pastures in Northeast Brazil. PLoS ONE 14(7): e0219343 https://doi.org/10.1371/journal.pone.0219343

Şahin Ö, Boztepe S \& Keskin İ (2018). Estimation of live weight, live weight gain and feed consumption values by using the means of body measurements of Anatolian Merino male lambs at fattening period. Selcuk Journal of Agriculture and Food Sciences, 32(2), 142-145 1 https://doi.org/0.15316/SJAFS.2018.76 (In Turkish)

Topal M \& Macit M (2004). Prediction of body weight from body measurements in Morkaraman sheep. Journal of Applied Animal Research 25(2): 97-100 https://doi.org/10.1080/09712119.2004.9706484

TurkStat (Turkish Statistical Institute) (2019). Livestock statistics http://www.turkstat.gov.tr (accessed March 27, 2020)

Vatankhah M \& Talebi M A (2008). Genetic parameters of body weight and fat-tail measurements in lambs. Small Ruminant Research 75(1): 1-6 https://doi.org/10.1016/j.smallrumres.2007.06.012

Wolf B T, Smith C, King J W B \& Nicholson D (1981). Genetic parameters of growth and carcass composition in the crossbred progeny of six terminal sire breeds of sheep. Animal Production 32: 1-7 https://doi.org/10.1017/S0003356100024703

Yilmaz A, Özcan M, Ekiz B \& Akgündüz M (2002). Investigations on the possibility of improving the meat poduction by crossbreeding Turkish Merino, Chios and K $>\mathrm{v}>\mathrm{rc}>\mathrm{k}$ sheep breeds 2. Fattening, slaughter and carcass characteristics of lambs. Turkish Journal of Veterinary and Animal Sciences 26: 1333-1340 (In Turkish)

Y1lmaz O, Cemal I \& Karaca O (2013). Estimation of mature live weight using some body measurements in Karya sheep. Tropical Animal Health and Production 45(2): 397-403 https://doi.org/10.1007/s11250-012-0229-7

(C) 2021 by the authors. Licensee Ankara University, Faculty of Agriculture, Ankara, Turkey. This article is an open access article distributed under the terms and conditions of the Creative Commons Attribution (CC BY) license (http://creativecommons.org/licenses/by/4.0/). 